\title{
$v-m y b$ and v-ets transform chicken erythroid cells and cooperate both in trans and in cis to induce distinct differentiation phenotypes
}

\author{
Thomas Metz and Thomas Graf \\ Differentiation Programme, European Molecular Biology Laboratory, 6900 Heidelberg, Germany
}

\begin{abstract}
E26 is an acute avian leukemia virus that encodes the transcriptional activator oncogenes $v$-myb and $v$-ets in a single fusion protein. This virus is also unique in that it is able to transform hematopoietic cells of both the myeloid and the erythroid lineage. To determine the contributions of $v-m y b$ and $v-e t s$ to the transforming potential of the virus, derivatives expressing separate Myb and Ets proteins, either alone or in combination, were constructed. We found that in the myeloid lineage v-myb, but not v-ets, induces cell transformation. In the erythroid lineage both $v$-myb and v-ets weakly transform erythroblast-like cells. These cells exhibit a mature phenotype and a low self-renewal capacity. The transforming efficiency of the two oncogenes is enhanced if they are coexpressed as separate proteins or as a fusion protein, the transformed cells displaying an increased self-renewal capacity. Interestingly, however, cells transformed by the Myb-Ets fusion protein have a distinct phenotype in that they are very immature. These results demonstrate that $v$-my $b$ and $v$-ets can cooperate in the transformation of erythroid cells both in trans and in cis and that the mode of cooperation is reflected by the differentiation phenotypes of the transformed cells.
\end{abstract}

[Key Words: v-myb; v-ets; myeloid and erythroid transformation; hematopoietic differentiation]

Received November 27, 1990; revised version accepted January 10, 1991.

Among the acutely leukemogenic chicken retroviruses, E26 is unique in several respects. First, it transduces two oncogenes, v-myb and v-ets /for review, see Shen-Ong 1990), both of which encode transcriptional activators (myb: Klempnauer et al. 1989; Ness et al. 1989; Nishina et al. 1989; Weston and Bishop 1989; Ibanez and Lipsick 1990; ets: Bosselut et al. 1990; Gunther et al. 1990; Ho et al. 1990; Wasylyk et al. 1990). Second, these two oncogenes are expressed as components of a single tripartite Gag-Myb-Ets fusion protein of $135 \mathrm{kD}$ molecular mass (referred to as Myb-Ets or Gag-myb-ets ${ }^{135}$ in the following), which is located in the nucleus (for review, see Shen-Ong 1990). Third, it causes predominantly an erythroleukemia but is also capable of transforming myeloid cells in vitro and in vivo, thus affecting two different lineages in the chicken hematopoietic system (Radke et al. 1982; Moscovici et al. 1983).

Although E26 was first isolated almost three decades ago and has been studied in some detail, it is still not clear how v-myb and v-ets contribute to its overall transforming potential. The role of $\mathrm{v}$-ets in transformation especially is poorly understood since no virus containing $\mathrm{v}$-ets alone has yet been isolated whose transforming capacity can be studied. In contrast, much more is known about the biological role of $\mathrm{v}-m y b$. The following lines of evidence indicate that the capacity of E26 to transform myeloid cells can be attributed to the Myb portion of the $135-\mathrm{kD}$ protein and that erythroid transformation is mediated by the Ets portion: (1) Another natural virus isolate exists (AMV), which transduces v-myb as its only oncogene and which transforms myeloblasts exclusively (for review, see Shen-Ong 1990); (2) mutant E26 viruses that lack the Ets portion of the $135-\mathrm{kD}$ protein are still able to transform myelobasts but not erythroblasts /Graf et al. 1987; Nunn and Hunter 1989); (3) myeloblasts transformed by ts21E26, a mutant with a lesion in v-myb (Frykberg et al. 1988), are temperature sensitive for transformation, whereas erythroid cells transformed by the same mutant are not (Beug et al. 1984). Conversely, erythroid cells transformed by ts1.1E26, a mutant with a lesion in v-ets, are temperature sensitive for erythroid but not for myeloid cell transformation (Golay et al. 1988).

However, there is also evidence that the effects of E26 on the myeloid and the erythroid lineages cannot be separated. For instance, the frequency of erythroid transformants induced by ts 21 E26 is significantly reduced relative to wtE26 (Beug et al. 1984; T. Graf, unpubl.). In addition, myeloid cells transformed by ts $1.1 \mathrm{E} 26$ express granules in their cytoplasm and thus show an altered phenotype when compared with wtE26-transformed myeloblasts (Golay et al. 1988). These observations suggest 
that $\mathbf{v}-m y b$ has some effect on erythroid transformation and that v-ets directly or indirectly affects the myeloid lineage.

In summary, although v-myb is clearly sufficient for the transformation of myeloblasts, the contribution of $\mathrm{v}-m y b$ and $\mathrm{v}$-ets to the transformation of erythroid cells is more complex. Several, not mutually exclusive, hypotheses can be postulated to explain the function of $\mathrm{v}$-ets in these cells. It is possible that v-ets does not affect erythroid cells directly but causes a conformational change in the Myb-Ets fusion protein that enables the Myb domain to transform erythroid cells. Another possibility is that both v-myb and v-ets contribute directly to the transformation of chicken erythroid cells, in which case they may be able to cooperate in trans. Finally, v-ets alone might be capable of transforming erythroid cells.

To distinguish between these possibilities, we constructed recombinant chicken retroviruses expressing both Myb and Ets as separate proteins, as well as viruses expressing either the Myb or Ets protein alone. We then compared their in vitro-transforming potentials with that of the original E26 virus, which synthesizes a MybEts fusion protein. (Transforming potential is operationally defined as the capacity to induce cells with an increased self-renewal capacity.) In addition, we characterized the differentiation phenotypes of erythroid cells transformed by the various viral constructs. We found that both v-myb and v-ets alone weakly transform and that they strongly transform if coexpressed from one virus, either as separate proteins or as a fusion protein. Interestingly, the phenotype of erythroid cells transformed by the fused Myb-Ets protein differs from those transformed by all other virus constructs in that these cells are highly immature and almost completely blocked in differentiation.

\section{Results}

Recombinant chicken retroviruses expressing $v$-myb and/or $v$-ets

The goal of this study was to determine the contributions of the viral $m y b$ and $e t s$ oncogenes to the erythroid and myeloid cell-transforming potential of the E26 virus. To achieve this goal, we generated recombinant chicken retroviruses that express both Myb and Ets as separate proteins (designated myb $\mathrm{b}^{77} / \mathrm{ets}^{68}$ and $\mathrm{myb}^{77} / \mathrm{ets}^{69}$; the superscripts indicate the molecular weights of the encoded proteins) or either Myb or Ets as their only proteins (designated myb ${ }^{77}$ or neo/ets ${ }^{68}$ and neo/ets ${ }^{69}$ ). Essentially, the separate Myb and Ets proteins consist of the truncated Gag-Myb or Ets portions of the E26-encoded 135-kD Myb-Ets fusion protein (Gag-myb-ets ${ }^{135}$ ) to which authentic carboxyl and amino termini were fused to ensure their stability. Since v-ets on its own is not known to exhibit any transforming potential, we included in the v-ets viruses the neo gene, encoding resistance against the drug G418, to allow for positive selection of cells infected by these viruses. A virus carrying the neo gene alone was used as a negative control. As all of these recombinant viruses express their proteins under the control of the long terminal repeats (LTRs) of avian erythroblastosis virus (AEV strain ES4; Vennström et al. 1980), we used as a reference virus a version of E26, designated myb-ets ${ }^{135}$, which likewise carries the AEV LTRs. This virus is indistinguishable from wild-type E26 virus in its biological properties (Introna et al. 1990). The genomic structures and protein products of these viruses are listed in Figure 1 and are described in detail in Materials and methods. Since subsequent experiments showed no biological difference between the $\mathrm{myb}^{77} / \mathrm{ets}^{68}$ and $\mathrm{myb}^{77} / \mathrm{ets}^{69}$ viruses or between the two viruses containing only v-ets (see below), we will collectively refer to them throughout the text as myb/ets and neo/ets viruses, respectively.

Both V-myb and $v$-ets transform erythroid cells but only $v$-myb transforms myeloid cells

To determine the in vitro-transforming potentials of the recombinant viruses we infected chicken bone marrow cells and monitored the outgrowth of transformed cells under both myeloid and erythroid culture conditions. These conditions specifically support the proliferation of transformed myeloid and erythroid cells, respectively (Radke et al. 1982). For this purpose, virus-producing chicken embryo fibroblasts (CEFs), which had been transfected with the proviral genomes and subsequently selected for G4 18 resistance, were cocultivated for 2 days with chicken bone marrow cells. Nonadherent cells then were serially transferred to fresh dishes every 2-4 days. As summarized in Table 1, all the v-myb-carrying

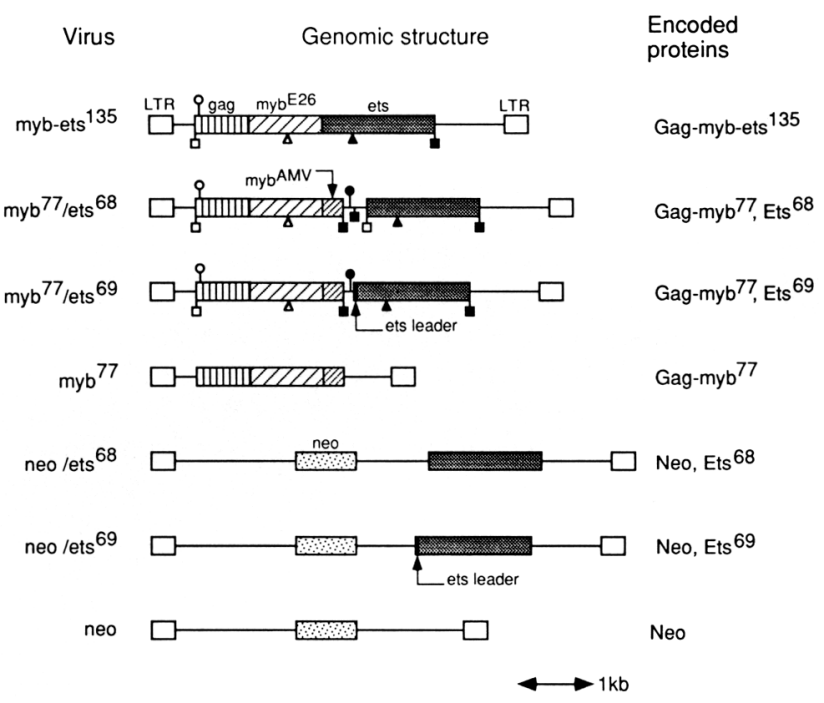

Figure 1. Viral constructs and their proteins. $(\Delta)$ Sall restriction site; $(\mathbf{\Delta})$ EcoRV restriction site; ( $\square$ ) translation initiation site $_{j}(\square)$ translation termination site; $(O)$ splice donor site; $(O)$ splice acceptor site. (LTR) Long terminal repeat; (Neo) neomycin phosphotransferase. For description of constructions, including the protein modifications introduced at the carboxyterminal end of Myb and the amino-terminal end of Ets, see Materials and methods. 
viruses, but not the viruses that express v-ets and/or neo alone, induced the outgrowth of transformed myeloid cells after 8-9 days (the lineages of the transformed cells were verified by immunofluorescence assays detecting myeloid- and erythroid-specific cell-surface antigens). In contrast, transformed erythroid cells were obtained with all v-ets-containing viruses but not with the myb virus or the neo virus. It took 12-14 days for the neo/ets viruses to transform erythroid cells, whereas transformed cells could already be seen 7-9 and 9-11 days after infection with the myb-ets and the myb/ets viruses, respectively. No transformed cells were observed in the uninfected or helper virus-infected control cultures.

We next tested the recombinant viruses in the blastoderm transformation assay (Moscovici et al. 1983). This system is particularly suited to produce transformed erythroid colonies. Briefly, cultures obtained from 2-day-old chicken blastoderms were infected with the viral supernatants harvested from the transformed bone marrow cultures and then seeded in semisolid medium under combined erythroid/myeloid growth conditions. Six to eight days later, large transformed colonies appeared in myb-ets, myb/ets, and myb virus-infected cultures, but not in cultures infected with neo/ets or neo viruses, nor in uninfected cultures. A number of transformed colonies were isolated for each construct and expanded in liquid medium, and their lineages were determined by immunofluorescence assays. As shown on the right side of Table 1, erythroid colonies were obtained not only with the myb-ets and the myb/ets viruses but unexpectedly also with the myb virus. In fact, the erythroid colonies transformed by the latter virus even outnumbered the transformed myeloid colonies by a factor of $\sim 10$. In addition, $\sim 12 \%$ of the myb-ets virus-transformed colonies were mixed, consisting of both myeloid and erythroid cells, as had already been described by Moscovici et al. (1983) for the E26 virus. On the basis of the results obtained in another study, it is probable that the majority of the mixed colonies originated from a single mul- tipotent progenitor (most colonies exhibited a single retroviral integration site). We also observed the outgrowth of transformed myeloid cells from $10-30 \%$ of erythroid colonies transformed by myb/ets and myb viruses after 2-3 weeks of culture under myeloid/erythroid growth conditions (T. Metz and T. Graf, unpubl.). In this case, whether the mixed colonies originated from a single infected target or from clumps of separately transformed erythroid and myeloid target cells remains to be determined.

To test whether the viruses synthesize the correct proteins, erythroid cells transformed by the various viral constructs were labeled with ${ }^{35} S \mid$ methionine and subjected to immunoprecipitation with antisera specific for either Myb or Ets proteins. As can be seen in Figure 2, each viral construct synthesized proteins of the expected sizes. These experiments also showed that erythroid cells transformed by the neo/ets virus express $\mathrm{Myb}^{75}$, the product of the endogenous c-myb proto-oncogene (see Discussion). As estimated from signal intensity ratios and the number of methionine residues per protein molecule, the expression level of Gag-myb-ets ${ }^{135}$ in transformed erythroid cells is on average 1.5- and 4-fold lower than that of separately expressed Myb and Ets proteins, respectively.

As we were not able to obtain individual transformed colonies with the neo/ets viruses, it is possible that expression of the oncogene in infected bone marrow cultures triggered accessory cells to induce the proliferation of erythroid cells. However, the fact that the transformed mass cultures expressed the viral Ets protein and grew in suspension, in the apparent absence of nonerythroid cells (T. Metz and T. Graf, unpubl.), suggests that erythroid cells are the primary targets of the v-ets oncogene. This interpretation is also supported by the ability of $\mathrm{v}$-ets to cooperate with $\mathrm{v}-\mathrm{myb}$ in the induction of rapidly proliferating erythroid colonies when expressed as a separate protein (see below).

In conclusion, all viruses that contain the v-myb on-

Table 1. Transforming capacities of viral constructs containing myb and ets oncogenes

\begin{tabular}{|c|c|c|c|c|c|c|}
\hline \multirow{2}{*}{$\begin{array}{l}\text { Infecting } \\
\text { virus }\end{array}$} & \multicolumn{2}{|c|}{$\begin{array}{c}\text { Bone marrow } \\
\text { cocultivation assay }^{a}\end{array}$} & \multirow{2}{*}{$\begin{array}{l}\text { Transformed } \\
\text { colonies }^{\mathrm{b}}\end{array}$} & \multicolumn{3}{|c|}{ Blastoderm Methocel assay } \\
\hline & myeloid & erythroid & & myeloid & erythroid & mixed \\
\hline myb-ets ${ }^{135}$ & +++ & ++ & 140 & $8 / 30^{c}$ & $18 / 30^{c}$ & $4 / 30^{c}$ \\
\hline $\mathrm{myb}^{77} / \mathrm{ets}^{68}$ & +++ & ++ & 150 & $2 / 36$ & $34 / 36$ & $?^{\mathrm{d}}$ \\
\hline $\mathrm{myb}^{77} / \mathrm{ets}^{69}$ & ++ & ++ & 72 & $3 / 27$ & $24 / 27$ & $?^{\mathrm{d}}$ \\
\hline $\mathrm{myb}^{77}$ & $++t$ & - & 100 & $2 / 28$ & $26 / 28$ & $?^{\mathrm{d}}$ \\
\hline neo/ets ${ }^{68}$ & - & + & 0 & NR & NR & NR \\
\hline neo/ets ${ }^{69}$ & - & + & 0 & NR & NR & NR \\
\hline neo & - & - & 0 & NR & NR & NR \\
\hline- & - & - & 0 & NR & NR & NR \\
\hline
\end{tabular}

(NR) Not relevant.

aProliferating cells of transformed morphology appeared under myeloid or erythroid culture conditions within $7-10(+++\mid, 10-12$ $1++1$, or $12-14$ days $1+1$.

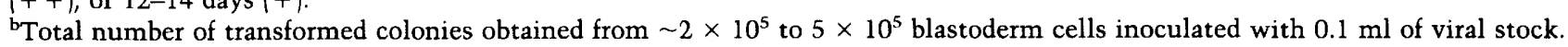

${ }^{\mathrm{c}}$ Number of myeloid, erythroid, or mixed colonies obtained over the number of colonies analyzed.

${ }^{\mathrm{d}}$ Myeloid cells developed in $\sim 20 \%$ of the erythroid colonies after $2-4$ weeks in culture (see text). 


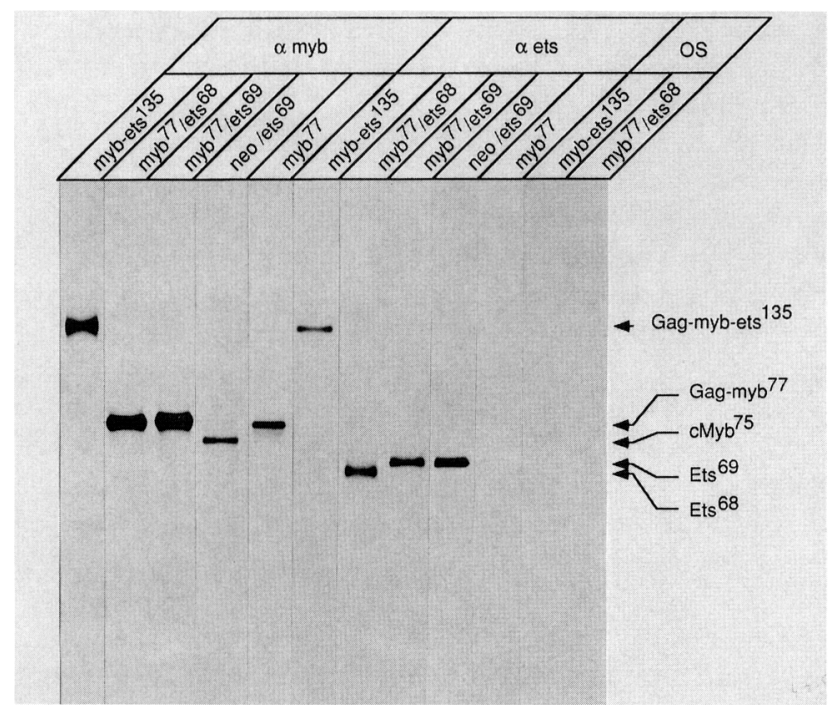

Figure 2. Expression of Myb and Ets proteins. $\left[{ }^{35} \mathrm{~S} \mid\right.$ Methioninelabeled lysates of erythroid cells transformed by the indicated viruses were immunoprecipitated with Myb- and Ets-specific antisera or with preimmune serum (OS for null serum). Exposure times of the films ranged from 1.5 days in the case of samples precipitated with anti-Ets sera to 8 days for those precipitated with anti-Myb sera. The protein sizes indicated were determined from the positions of standard proteins (not shown).

cogene transform myeloid cells, whereas all viruses that synthesize either Myb or Ets proteins, or a combination of both, transform cells of the erythroid lineage. However, v-ets-transformed erythroid cells grew only out of bone marrow, whereas $\mathrm{v}$-myb-transformed erythroid cells could only be obtained from blastoderm cultures.
Erythroid cells transformed by the various $v$-myb and $v$-ets virus constructs display striking differences in their differentiation phenotypes

Microscopic inspection of erythroid cells transformed by the various virus constructs revealed major differences. The myb-ets virus induced very compact colonies in Methocel cultures, whereas myb/ets and myb viruses formed large burst-like colonies containing compact subcolonies (Fig. 3, top). In liquid culture, myb-ets virustransformed cells developed into chains or large aggregates (Fig. 3, bottom) with variable proportions of single, often dead cells and occasional erythrocyte-like cells. In comparison, cultures transformed by all other constructs grew mostly as dispersed cell suspensions, containing high proportions of mature erythroid cells and occasional aggregates.

As summarized in Table 2, the phenotypes of erythroid cells transformed by the various constructs were characterized in more detail in comparison to erythroblasts transformed by the v-erbB-containing AEV strain $\mathrm{H}(\mathrm{AEV}-\mathrm{H})$. Cells transformed by all viral constructs were essentially $100 \%$ positive for the expression of "erythroblast antigen," as detected by immunofluorescence staining with a polyclonal rabbit serum (Beug et al. 1979; data not shown). Histone 5, a marker for avian erythroid and megakaryocytic cells, was expressed in nearly all of the myb/ets- and v-erbB-transformed cells. In contrast, between $10 \%$ and $40 \%$ of the myb-ets vinustransformed cells were negative for histone 5 . To analyze the spontaneous differentiation potential of the transformed erythroid cells, we determined hemoglobin expression using two variants of the benzidine staining technique. Benzidine staining at acid $\mathrm{pH}$ revealed that 2 -week-old cultures of myb-ets virus-transformed ery-
Figure 3. Morphology of erythroid cells transformed by myb-ets ${ }^{135}$ and myb $^{77} /$ ets $^{68}$ viruses. Micrographs of transformed erythroid colonies in Methocel cultures 8 days after infection of chicken blastoderm (top). Phase-contrast micrographs of individual colonies in liquid culture 5 days after isolation from Methocel (bottom).

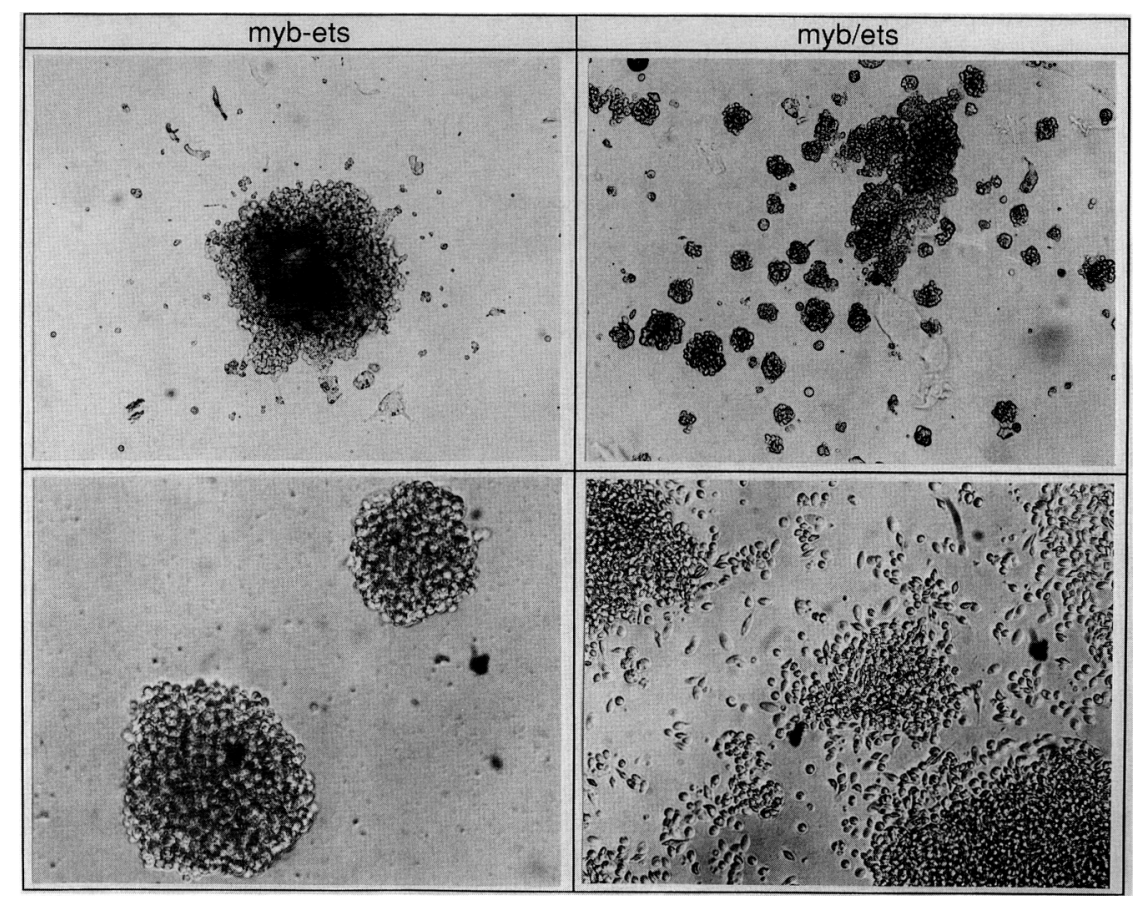


Table 2. Phenotypes of transformed primary avian erythroid cells

\begin{tabular}{|c|c|c|c|c|c|c|c|}
\hline \multirow{2}{*}{$\begin{array}{l}\text { Transforming } \\
\text { virus (oncogene) }\end{array}$} & \multirow[b]{2}{*}{ Hemoglobin $^{a}$} & \multirow[b]{2}{*}{ Histone H5 } & \multicolumn{5}{|c|}{ Cell-surface antigens } \\
\hline & & & MEP17 & MEP21 & MEP26 & JS3 & JS4 \\
\hline myb-ets ${ }^{135}$ & 4.6 & 74 & 82 & 85 & 99 & 0 & 0 \\
\hline $\mathrm{myb}^{77} / \mathrm{ets}^{68}$ & $83^{b}$ & 97 & 4 & 23 & 71 & 0 & 70 \\
\hline neo/ets ${ }^{69}$ & $90^{c}$ & ND & 20 & 8 & 70 & 0 & 100 \\
\hline $\mathrm{myb}^{77}$ & 95 & ND & 8 & 10 & 90 & 0 & 98 \\
\hline $\mathrm{AEV}-\mathrm{H}(e r b \mathrm{~B})$ & 72 & ND & 0 & 0 & 85 & 100 & 100 \\
\hline
\end{tabular}

(ND) Not determined.

Values in the upper two rows represent average percentage marker-positive cells determined from 6 (37 for hemoglobin) individually transformed clones. Values in the lower three rows represent the average of two measurements performed on cell pools.

apercent acid benzidine-positive cells in 2-week-old cultures. The proportion of hemoglobin-positive cells is slightly higher in clones freshly transformed by myb-ets or myb/ets viruses.

${ }^{b}$ Similar values were obtained with $\mathrm{myb}^{77} / \mathrm{ets}^{69}$-transformed clones.

${ }^{\mathrm{c}} \mathrm{Similar}$ values were obtained with neo/ets ${ }^{68}$-transformed cells.

throid cells contained, on average, $<5 \%$ hemoglobinpositive cells. In contrast, in transformed cultures obtained with all other viruses, the average proportion of hemoglobin-positive cells exceeded $70 \%$ (Table 2; Fig. 4). Cytospin preparations stained with neutral benzidine and counterstained with Giemsa gave similar results, although the proportions of benzidine-positive cells in all samples were two to three times lower. The cytospin preparations also confirmed the observation that myb/ ets or myb virus-transformed cells are capable of differentiating into mature erythrocytes. However, erythroid differentiation in neo/ets and (occasionally) in myb-ets virus-transformed cultures seemed to be mostly aberrant, usually leading to the death of differentiating cells before they matured fully (Fig. 5). In conclusion, all of the recombinant viruses except the myb-ets virus transform relatively mature erythroblast-like cells with a high spontaneous differentiation potential.

The phenotype of the transformed erythroid cells was characterized further by a determination of their cellsurface antigen expression (Table 2 ). We recently developed three monoclonal antibodies against cell-surface antigens (MEP17, MEP21, and MEP26) that are highly expressed by erythroid cells transformed by the myb-ets virus (T. Graf et al., in prep.). Although erythroid cells transformed by all viruses strongly express the MEP26 antigen, the MEP17 and MEP21 antigens are highly expressed only by myb-ets virus-transformed cells and are completely absent from v-erbB-transformed cells. Conversely, the JS4 antigen (a marker for relatively mature erythroid cells; Schmidt et al. 1986) is highly expressed on all transformed cells that exhibit a mature phenotype but not on myb-ets virus-transformed cells. Finally, the expression of the JS3 antigen (probably representing glycophorin; Schmidt et al. 1986; M. Hayman and H. Beug, pers. comm.) is high on v-erbB-transformed erythroblasts but totally absent from all v-myb-and/or v-ets-transformed erythroid cells.

A problem that generally hampers the study of primary oncogene-transformed avian hematopoietic cells is their limited lifespan (see below). Therefore, we attempted to establish cell lines from the different types of erythroid cells described. As described in Table 3, we succeeded in establishing three erythroid cell lines transformed by myb-ets virus and two erythroid cell lines transformed by myb/ets viruses by prolonged culture of selected blastoderm-derived transformed colonies. These cell lines (denoted with HD for Heidelberg) have been maintained for $>1 \mathrm{yr}$ in continuous culture and exhibit population doubling times of 22-24 hr and high cloning efficiencies in Methocel cultures (T. Graf, unpubl.). In

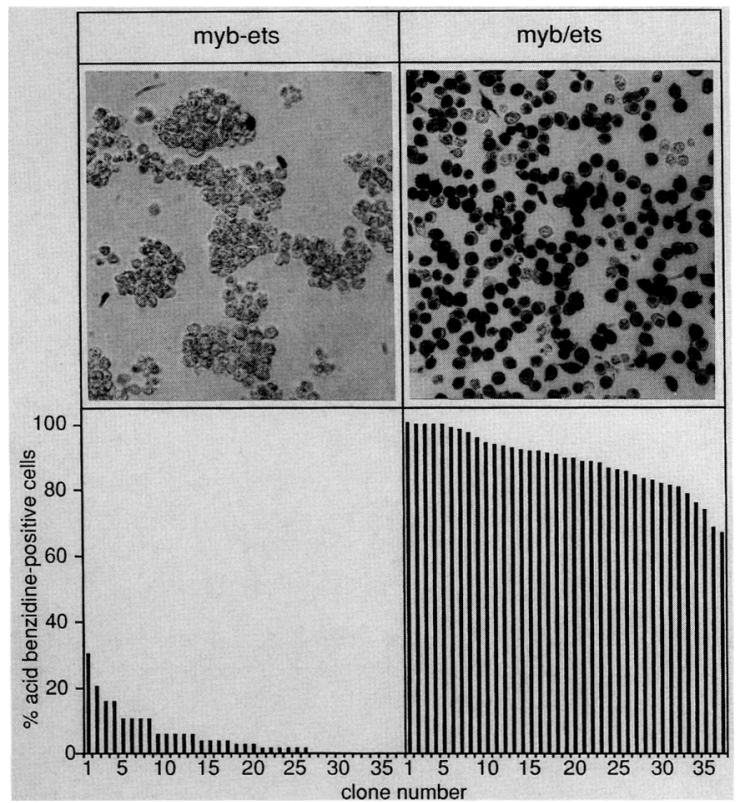

Figure 4. Hemoglobin expression of erythroid cells transformed by myb-ets and myb/ets viruses. Thirty-seven erythroid colonies transformed by either myb-ets ${ }^{135}$ or myb $^{77} / \mathrm{ets}^{68}$ virus were isolated, expanded in liquid medium, and analyzed for hemoglobin expression by staining with benzidine at acid $\mathrm{pH}$. Two of these clones are shown in the micrographs at top (benzidine-positive cells are black). The histograms at bottom show the distribution of hemoglobin expression in individual clones. The clones were ordered according to their proportion of hemoglobin-positive cells. 
Figure 5. Cytochemical characterization of erythroid cells transformed by various viral constructs. Blastoderm-derived erythroid colonies transformed by myb-ets ${ }^{135}$, myb $^{77} /$ ets $^{68}$, and $\mathrm{myb}^{77}$, and a bone marrow-derived culture transformed by neo/ets ${ }^{68}$ were subjected to cytocentrifugation, stained with benzidine at neutral $\mathrm{pH}$, and counterstained with Giemsa. Cells with a high hemoglobin expression stain golden brown, cells with intermediate expression stain grey to green, and negative cells stain blue.

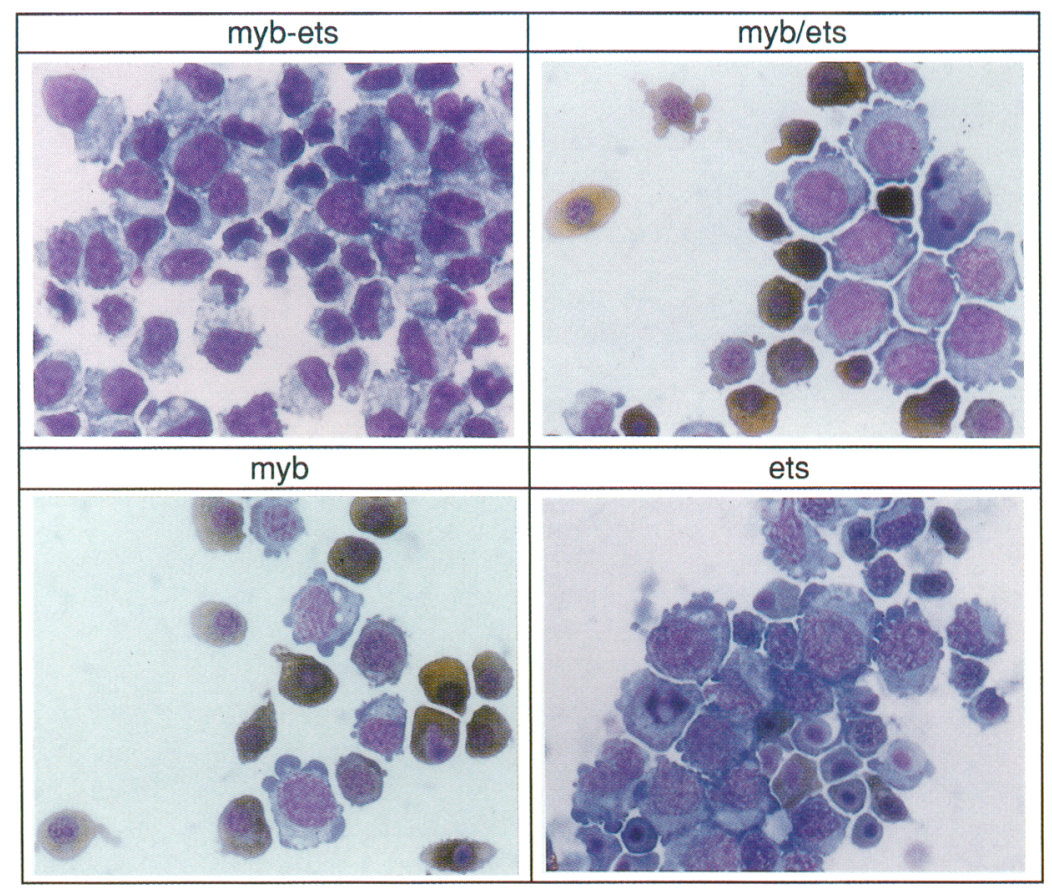

general, their phenotypes resembled those of the original transformants. However, the myb/ets virus-transformed cells ceased to synthesize hemoglobin and failed to express the JS4 antigen, and one line (HD44) exhibited an increased expression of MEP17 antigen. In addition, one of the myb-ets virus-transformed cell lines (HD51) ceased to express the MEP17 antigen. Since the viruses produced by all cell lines had properties indistinguishable from the parental virus strains, secondary changes in the cellular genome must have led to the alterations in the phenotypes of the cells. The lines described may become useful for further studies on the differences in the gene expression pattern between myb-ets- and myb/ ets-virus-transformed cells.

In summary, the v-myb and v-ets oncogenes transform immature erythroid cells only when their products are expressed as a fusion protein. When their products are expressed separately they transform erythroid cells with a high spontaneous differentiation potential. The v-erbBtransformed erythroblasts are likewise relatively mature but exhibit a different cell-surface antigen pattern. The various phenotypes and their implications will be discussed in more detail later (see Fig. 8, below, and Discussion).

Erythroid cells transformed by the myb, myb/ets, and myb-ets viruses differ in their self-renewal capacities

The results presented so far showed no clear differences between the phenotypes of erythroid cells transformed by the myb/ets, myb, or neo/ets viruses. This raised the question whether v-myb and v-ets cooperate only in cis (i.e., when expressed as a fusion protein) or whether they also cooperate in trans (i.e., when expressed as separate proteins). That the latter is the case is indicated by the observation that erythroid cells transformed by the var-

Table 3. Phenotypes of transformed avian erythroid cell lines

\begin{tabular}{|c|c|c|c|c|c|c|c|c|}
\hline \multirow{2}{*}{$\begin{array}{l}\text { Designation } \\
\text { of cell line }\end{array}$} & \multirow{2}{*}{$\begin{array}{l}\text { Transforming } \\
\text { virus } \\
\text { (oncogene) }\end{array}$} & \multirow[b]{2}{*}{ Hemoglobin $^{a}$} & \multirow[b]{2}{*}{ Histone $\mathrm{H} 5$} & \multicolumn{5}{|c|}{ Cell-surface antigens } \\
\hline & & & & MEP17 & MEP21 & MEP26 & JS3 & JS4 \\
\hline $\mathrm{HD} 24$ & myb-ets $^{135 b}$ & 0 & 100 & 99 & 100 & 98 & 1 & 0 \\
\hline HD51 & myb-ets ${ }^{135 b}$ & 0 & 97 & 1 & 98 & 99 & 0 & 0 \\
\hline HD57 & myb-ets ${ }^{135} \mathrm{~b}$ & 0 & 89 & 85 & 95 & 95 & 0 & 0 \\
\hline HD37 & $\mathrm{myb}^{77} / \mathrm{ets}^{68}$ & 0 & 100 & 3 & 1 & 99 & 7 & 0 \\
\hline HD44 & $\mathrm{myb}^{77} / \mathrm{ets}^{68}$ & 0 & 96 & 57 & 3 & 90 & 0 & 0 \\
\hline \multirow[t]{2}{*}{ HD3 } & AEV-ES4 & & & & & & & \\
\hline & $|e r b A, e r b B|$ & 4 & 100 & 0 & 0 & 0 & 100 & 100 \\
\hline
\end{tabular}

Values represent percentage marker-positive cells.

${ }^{\text {a Percent }}$ acid benzidine-positive cells.

${ }^{b}$ The original E26 virus was used. 
ious virus constructs displayed striking differences in their self-renewal capacities, as evident from their population doubling times and population doubling capacities. Thus, the best growing colonies transformed by the myb-ets or myb/ets viruses doubled about every 20-30 $\mathrm{hr}$, whereas those transformed by the myb virus doubled only about every 60-80 $\mathrm{hr}$ (data not shown). In addition, myb virus-transformed erythroid colonies doubled on average $\sim 10-15$ times, whereas myb/ets virus-transformed colonies doubled $\sim 30$ times and myb-ets virustransformed colonies doubled $\sim 40$ times before they senesced (Fig. 6). It was more difficult to assess the population doubling capacity of neo/ets virus-transformed cells because we were not able to obtain individually transformed colonies. As a rough estimate, knowing that $<0.1 \%$ of the bone marrow cells can be transformed by E26 (Radke et al. 1982), and based on the finding that $\sim 20 \times 10^{6}$ transformed erythroid cells could be obtained from $20 \times 10^{6}$ neo/ets-infected bone marrow cells, an average population doubling capacity of transformed cells of 11 can be calculated. This estimate would increase if the actual number of target cells was lower.

In summary, three different types of transformed erythroid cells can be distinguished by their capacity for self-renewal. Cells transformed by either v-myb or v-ets grow slowly and have a short lifespan. Cells expressing both oncogenes as separate proteins grow significantly faster and have an increased lifespan. Finally, cells transformed by the Myb-Ets fusion protein also grow relatively fast but exhibit an additional increase in their lifespan. These results thus demonstrate that the two oncogenes can cooperate both in cis and in trans.

Expression of a separate viral Ets protein in $v$-myb-transformed myeloid cells does not alter their phenotype

Myeloblasts transformed by the myb-ets virus are essentially free of granules. In contrast, cells transformed by tsl.1E26, a mutant with a lesion in the Ets portion of the

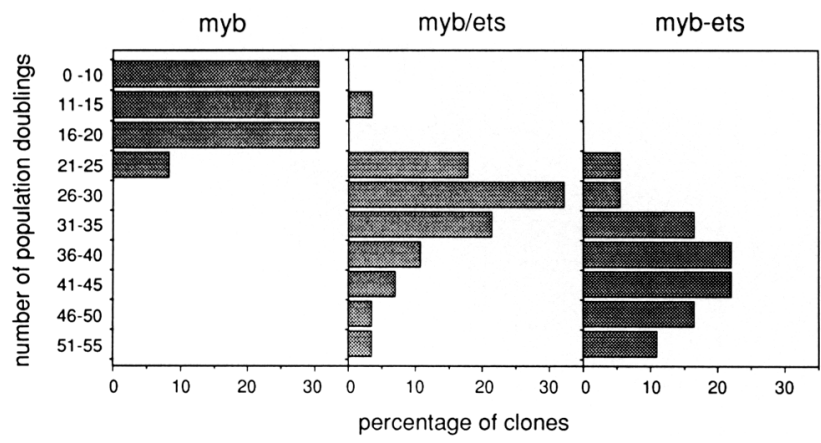

Figure 6. Population doubling capacities of transformed erythroid colonies. Thirty blastoderm-derived erythroid colonies transformed individually by either myb-ets ${ }^{135}$, myb $^{77} / \mathrm{ets}^{68}$, or $\mathrm{myb}^{77}$ viruses were cultured until senescence. The cumulative cell number determined for each colony was then used to calculate the number of total population doublings. The clones were grouped into 10 categories as indicated on the $y$-axis.

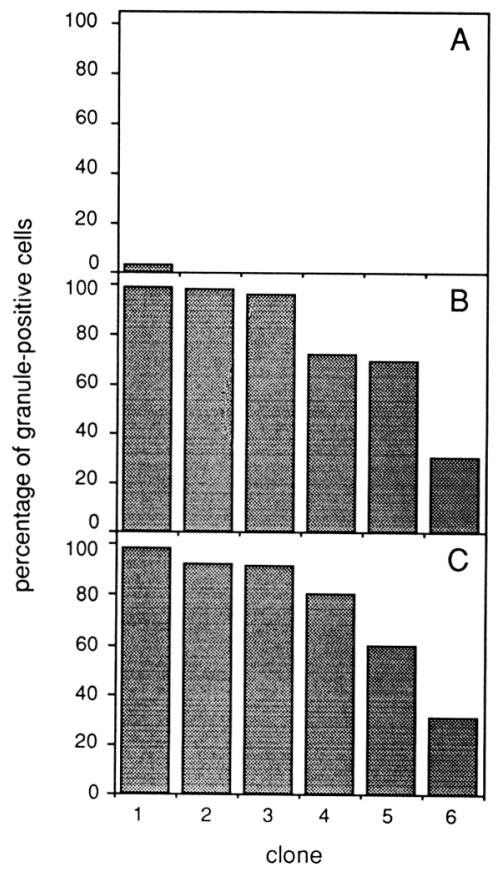

Figure 7. Frequency of granule-positive cells in transformed myeloid colonies. Six blastoderm-derived myeloid colonies transformed individually by either myb-ets ${ }^{135}(A), \operatorname{myb}^{77}(B)$, or $\mathrm{myb}^{77} / \mathrm{ets}^{68}|C|$ viruses were cytocentrifuged and stained with Giemsa. The percentage of granule-positive cells was scored and ordered according to their proportion of granule-positive cells.

Myb-Ets fusion protein, have a large number of granules in their cytoplasm and thus resemble chicken promyelocytes (Golay et al. 1988). This observation suggests that $\mathrm{v}$-ets suppresses granule formation and that if $\mathrm{mu}$ tated, this function is abolished. Like ts1.1E26, the myb $^{77}$ virus (also called EEA; Introna et al. 1990) transforms heavily granulated myeloid cells (Introna et al. 1990, and below). To determine whether v-ets expressed as a separate protein in myb ${ }^{77}$ virus-transformed cells can suppress granule formation, myb-ets, myb/ets, or myb virus-transformed myeloid colonies were examined for granule expression. As shown in Figure 7, no difference in granule expression of colonies transformed by myb virus as compared to myb/ets virus could be detected, both types of cells being highly positive, whereas most colonies transformed by myb-ets virus were negative for granule expression. This indicates that a separate Ets protein does not suppress granule formation in $\mathrm{v}$ myb-transformed myeloid cells, raising the possibility that granule suppression by the Ets domain of the MybEts fusion protein is indirect and due to a modulation of the Myb domain.

\section{Discussion}

Transforming potentials and cooperativity between $v$-myb and $v$-ets

We analyzed the contributions of the v-myb and v-ets genes to the transforming potential of the E26 virus in 
vitro and found that v-myb but not v-ets is capable of transforming myeloid cells. In the erythroid lineage, as summarized in Figure 8, recombinant viruses synthesizing either Myb or Ets as their only oncoprotein yield transformed cells with a high spontaneous differentiation potential and a low capacity for self-renewal (weak transformed phenotype). Viruses coexpressing separate Myb and Ets proteins yield transformed erythroid cells with similar properties, except that they have an increased self-renewal capacity (intermediate transformed phenotype). Finally, the E26 virus, which expresses a Myb-Ets fusion protein, transforms very immature erythroid cells that are tightly blocked in differentiation and have a high self-renewal capacity (strong transformed phenotype). These observations provide the first example for two levels of oncogene cooperativity that depend on whether the oncoproteins are expressed separately (trans-cooperativity) or whether they are fused into a single molecule (cis-cooperativity). Studies in progress indicate that only viruses expressing Myb-Ets fusion proteins are leukemogenic, whereas virus constructs that synthesize separated Myb and Ets proteins are not $(T$. Metz and T. Graf, in prep.).

The finding that the myb ${ }^{77}$ virus is capable of transforming erythroid cells is surprising because v-myb-containing viruses have only been reported to transform myeloid cells so far. The erythroid cell-transforming potential of the $\mathrm{myb}^{77}$ virus is not due simply to the particular culture conditions employed in the present study since $A M V$, which contains a slightly different form of $\mathbf{v}-m y b$ (the former encodes $272 \mathrm{gag}-, 362 \mathrm{myb}$-, and $11 \mathrm{env}-$ derived amino acids, the latter encodes 6 gag-, $371 \mathrm{myb}$-, which also harbor 9 amino acid differences, and $11 \mathrm{env}$ derived amino acids), does not exhibit any erythroid celltransforming activity under the same conditions ( $T$. Graf, unpubl.). On the other hand, it has been demonstrated that overexpression of c-myb can block the differentiation of mouse erythroleukemia cells (for review, see Shen-Ong 1990). It remains to be worked out which domains of $\mathrm{v}-m y b$ are required for its erythroid celltransforming potential. Also, it will be interesting to determine whether or not $\mathrm{v}-\mathrm{my} b$ of AMV can cooperate with v-ets in erythroid cell transformation. The demonstration of the erythroid cell-transforming potential of $\mathrm{v}$-ets is in agreement with the finding that the product of the Spi-1/Pu.1 gene, which has a DNA-binding domain very similar to that of Ets proteins (Moreau-Gachelin et al. 1989; Klemsz et al. 1990), is likely to be involved in the induction of erythroblastosis by spleen focus forming virus (SFFV) in mice (Moreau-Gachelin et al. 1988).

\section{Different erythroid target cells?}

On the basis of their state of maturation and cell-surface antigen expression pattern, transformed erythroid cells can be classified into several categories that differ somewhat from those discussed above (Fig. 8). Cells transformed by separate Myb and Ets proteins or by either of them alone are relatively mature and have a similar pattern of cell-surface antigen expression. They can thus be grouped into a first category. The myb-ets virus-transformed cells, which are characterized by their immature phenotype and the expression of a distinct but partially overlapping pattern of antigen expression, form a second category. These cells actually represent multipotent progenitors that can be induced to differentiate along the myeloid and eosinophilic lineage (T. Graf et al., in prep.). Finally, v-erbB-transformed cells represent yet a third category of relatively mature cells that differ dramatically from the first two in their cell-surface antigens. These findings raise the possibility that Myb-Ets transforms an early erythroid progenitor, whereas separate Myb and Ets proteins on the one hand and ErbB on the other hand transform two different types of committed precursors. The observation that the neo/ets ${ }^{68}$ and neo/ ets ${ }^{69}$ viruses only seem to transform bone marrow cells, whereas the $\mathrm{myb}^{77}$ vinus appears to transform predominantly blastoderm-derived erythroid cells suggests that
Figure 8. Schematic representation of chick erythroid cells transformed by various oncogenes or oncogene combinations. Different types of transformed erythroid cells are represented in separate boxes. Erythroid differentiation is represented as a continuum of immature cells $(t o p)$ to mature cells (bottom). (Top) Uncommitted progenitor; (middle) committed progenitor; (bottom) erythrocyte. Transformed cells are indicated by continuous circles, normal cells by broken lines. (Straight arrows) Differentiation; (curved arrows) self-renewal. Size of arrows indicates the relative contributions of differentiation vs. selfrenewal. Cell-surface antigens are indicated by open triangles (MEP17, MEP21), circles (JS4), or squares (JS3) outside of the large circles. (MEP26 is not represented in this scheme since it is expressed in all transformed cell types.) One symbol indicates low expression; three symbols indicate high expression.

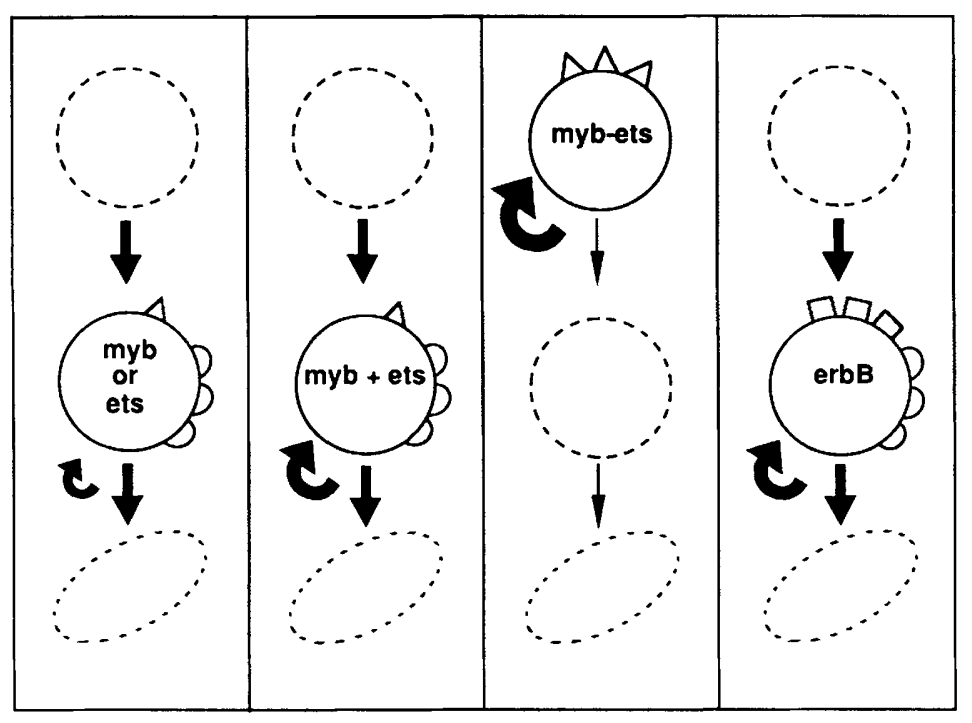


the two types of virus affect different target cells. However, these results do not fit into a simple scheme reflecting the different transformed cell phenotypes observed. It will now be interesting to determine whether the antigens detected on the surface of the various transformed cells are also expressed on normal cells and, if so, whether subpopulations of erythroid cells can be distinguished. Perhaps in addition to the existence of distinct target cells, expression of different oncogenes within one target cell population can induce different phenotypic changes. Superinfection experiments introducing additional oncogenes in transformed erythroid cells might help to clarify this issue.

Another question related to these problems is what are the growth requirements of the various types of transformed cells? The finding that all cells transformed by either $\mathrm{v}-m y b$ or by $\mathrm{v}$-ets alone or by their combination grew in the absence of added factors, in contrast to verbA-transformed cells, which require anemic serum enriched in erythropoietin (Gandrillon et al. 1989; T. Metz and $T$. Graf, unpubl.), suggests that they are factor independent. However, since the medium used in our experiments contained fetal calf serum, chicken serum, and insulin, it remains to be tested whether they require low concentrations of erythropoietin, other factors provided by the serum, or insulin.

\section{What is the molecular basis of the cooperativity} between Myb and Ets?

Myb and Ets are transcriptional activators containing both DNA-binding and trans-activation domains. Because v-myb and v-ets are capable of weakly transforming erythroid cells on their own, the activation of genes regulated by either oncogene alone seems to be sufficient for transformation. The simplest explanation for the enhanced self-renewal capacity of erythroid cells expressing both proteins is that the effects of Myb- and Etsregulated genes on the transformed phenotype are additive. Myb and Ets could also synergize in the transcriptional activation of particular genes as has been suggested for the cooperation between c-Ets and AP-1 (Wasylyk et al. 1990).

It is more difficult to explain the second level of cooperativity observed with the fusion protein. Increased expression levels of Gag-myb-ets ${ }^{135}$ protein relative to the separated proteins can be ruled out since, in transformed erythroid cells, we found at least equal if not higher amounts of the latter proteins as compared to the former. Differences in subcellular localization are also unlikely since the fusion protein Myb, as well as Ets-1, is localized predominantly in the nucleus (Boyle et al. 1984; Klempnauer et al. 1984; Leprince et al. 1990). Moreover, the carboxy- and amino-terminal modifications of the separated Myb and Ets proteins relative to the E26 Myb and Ets portions most probably do not interfere with domain functions, as illustrated by the strong myeloid cell-transforming potential of Gagmyb $^{77}$ (which has a modified carboxyl terminus) and the finding that $\mathrm{Ets}^{68}$ and $\mathrm{Ets}^{69}$ (which differ in their amino termini) exhibit identical biological properties. The observations that a viral construct expressing the unmodified Gag-Myb portion of Gag-myb-ets ${ }^{135}$, along with $\mathrm{Ets}^{68}{ }^{6}$, does not differ from $\mathrm{myb}^{77} / \mathrm{ets}^{68}$ virus in its transforming potential and that variants of myb-ets ${ }^{135}$ virus with 5 -terminal deletions in their v-ets portion do not differ biologically (T. Metz and T. Graf, in prep.), further support this notion. Therefore, we speculate that the fusion of Myb and Ets domains generates a qualitatively new transcriptional activator, possibly by creating altered DNA-binding specificities and/or affinities. Another possibility is that the fusion protein exhibits an enhanced trans-activation potential because it contains the trans-activation domains of both Myb and Ets proteins. Finally, it is tempting to speculate that Myb and Ets form a heterodimer analogous to that known for the nuclear oncoproteins Jun and Fos (for review, see Curran and Franza 1988). Covalent linkage of Myb and Ets into one molecule could thus increase their transcription activation potential, especially if assembly of the complex from separate Myb and Ets proteins is otherwise rate limiting. However, attempts to demonstrate a direct association between Myb and Ets have failed so far (F. Lim and T. Graf, unpubl.), and there are no obvious dimerization motifs present in the proteins that would predict their association.

Such speculations also raise the interesting question of whether erythroid cell transformation by v-ets requires $c-m y b$ expression and whether transformation by $\mathrm{v}-m y b$ requires c-ets-1 expression. The observation that c-myb is highly expressed in v-ets-transformed erythroid cells would support this idea. However, it is unclear whether this reflects the expression state of $c-m y b$ in uninfected target cells or whether c-myb is induced by v-ets in these cells. The finding that $c-m y b$ is not expressed in cells transformed by both $\mathrm{v}-m y b$ and $\mathrm{v}$-ets is compatible with the notion that $\mathrm{v}-m y b$ suppresses $\mathrm{c}-\mathrm{my} b$ in some, but not all, cell types (Lipsick 1987). More work is clearly necessary to determine the role of c-myb and c-ets in the transformation of erythroid cells.

\section{Materials and methods}

Construction and genomic organization of recombinant viruses

The genomes of all recombinant chicken retrovinuses were contained in a proviral form in a plasmid vector backbone (pCR-1; Frykberg et al. 1988), which contains the neo gene and confers resistance to the drug G418.

The virus designated as myb-ets ${ }^{135}$ is identical to the pMI3 virus described earlier (Golay et al. 1988) and contains the genome of E26 with LTRs of AEV strain ES4. Immediately 3' of the ets-coding region are the restriction sites XhoI, KpnI, SstI, and EcoRI, which were used for further constructions (see below).

For the construction of the myb $\mathrm{b}^{77} / \mathrm{ets}^{68}$ virus, the 660 -bp SallSacI DNA fragment of the CRmyb-HER virus (T. Metz et al., in prep.), which contains (from $5^{\prime}$ to $3^{\prime}$ ) the $3^{\prime}$-terminal 449-bp of the AMV-myb-coding region, including the termination codon, the modified splice acceptor of AEV strain ES4, and a stop codon (in the correct reading frame to stop gag-initiated translations 
from spliced messages) was subcloned into pGemI (Promega Biotecl. Subsequently, the chicken c-ets-1 complementary DNA (Leprince et al. 1988) was inserted as an EcoRI fragment in the EcoRI site just 3' of the stop codon in the appropriate orientation to place its Kozak sequence (Kozak 1984) and its start codon next to the stop codon. These sequences were inserted as a 1250-bp SalI-EcoRV DNA fragment into the myb-ets ${ }^{135}$ virus to replace the 688-bp SalI-EcoRV DNA fragment of the latter encompassing the junction between $\mathrm{v}-m y b$ and v-ets (Fig. 1). The resulting virus translates Gag-myb ${ }^{77}$ from an unspliced genomic message and $E t^{68}$ from a spliced subgenomic message. Gag-myb ${ }^{77}$ (referred to as Myb) consists of the E26 Gag-Myb portion (555 amino acids) with the 90 carboxy-terminal amino acids of AMV-Myb fused to it. The Ets ${ }^{68}$ protein (488 amino acids) has the amino terminus of the Ets-1 protein (encoded by the proto-oncogene c-ets-1; Leprince et al. 1988) and thus differs from the Ets portion of E26 (491 amino acids) only by the absence of the three amino-terminal amino acids of the latter, which originate from the untranslated leader of c-ets-1 (Leprince et al. 1988). The splicing results from the interaction of the splice donor site in gag with the introduced splice acceptor site in the intergenic region between myb and ets. The subgenomic message contains two open reading frames. The first encodes a small peptide that starts at the AUG in gag and terminates at the stop codon $3^{\prime}$ of the splice acceptor. The authentic start site of the c-ets-1 gene, which is preceded by a Kozak sequence (Kozak 1984), allows translation to reinitiate into the second open reading frame that extends to the termination codon of ets, yielding the Ets ${ }^{68}$ protein (see also Fig. 1).

To construct the $\mathrm{myb}^{77} / \mathrm{ets}^{69}$ virus, the HindIII fragment of the c-ets-1 cDNA was inserted into the HindIII site of CRmybHER (Metz et al. 1991). The 1100-bp Sall-EcoRV DNA fragment of this construct replaced the corresponding 688-bp DNA fragment of the myb-ets ${ }^{135}$ virus. The resulting myb $\mathrm{m}^{77} / \mathrm{ets}^{69} \mathrm{vi}$ rus is structurally identical to the myb $b^{77} /$ ets $^{68}$ virus except that it lacks the stop codon $3^{\prime}$ of the splice acceptor so that gaginitiated translation from the subgenomic message is not interrupted but is allowed to continue to the ets termination codon yielding Ets ${ }^{69}$ (Fig. 1). Relative to Ets ${ }^{68}$, it contains 6 additional amino acids from Gag and 14 additional amino acids derived from the untranslated leader of the c-ets-1 gene (Leprince et al. 1988 ) at its amino terminus (i.e., 14 additional amino-terminal amino acids, compared with the Ets portion of E26).

The construction of the myb $\mathrm{b}^{77}$ virus (previously called CRmyb) has been described (Metz et al. 1991). A virus construct (called EEA), which also encodes $\mathrm{Gag}-\mathrm{myb}^{77}$, was described by Introna et al. (1990).

The neo virus was kindly provided by Scott Ness. It was constructed by subcloning the neo-containing Xhol-KpnI DNA fragment of pNEO-AMV (Lipsick et al. 1986) into SFCV-BXA (Fuerstenberg et al. 1990).

To create the neo/ets ${ }^{68}$ virus, the myb-containing SacII-SalI DNA fragment of the myb ${ }^{77} /$ ets $^{68}$ virus was substituted by the neo-containing SacII-SalI DNA fragment of the neo virus.

The neo/ets ${ }^{69}$ virus was constructed by replacing the SalI DNA fragment of the neo virus by the ets-containing Sall-XhoI DNA fragment of the $\mathrm{myb}^{77} / \mathrm{ets}^{69}$ virus.

\section{Cells}

All cells were derived from chickens of the white leghorn Spafas flock maintained in Heidelberg. CEFs were grown in standard growth medium, consisting of Dulbecco's modified Eagle medium (DMEM) containing $8 \%$ fetal calf serum, $2 \%$ chicken serum, and $10 \mathrm{mM}$ HEPES buffer.

\section{Transfection of CEFs}

Primary CEFs were transfected with $10 \mu \mathrm{g}$ of virus DNA, together with $2 \mu \mathrm{g}$ of RAV-1 DNA, as described earlier (Frykberg et al. 1988), to allow for virus spread (all viruses were used as RAV-1 pseudotypes). The cells were selected for G418 resistance 2 days after transfection in medium containing $800 \mu \mathrm{g} / \mathrm{ml}$ G418 (GIBCO).

In vitro transformation of bone marrow cells and production of virus

Bone marrow cells were isolated from 1- to 2-week-old chicks, from which erythrocytes were removed by a Ficoll centrifugation step (Graf et al. 1981). For transformation $20 \times 10^{6}$ cells were cocultivated with $5 \times 10^{5}$ virus-producing CEFs in $50-\mathrm{mm}$ dishes under myeloid or erythroid conditions (see below). Two days later, the nonadherent cells were transferred to fresh dishes, and this procedure was repeated every 2-4 days until no more cells were present in the uninfected control cultures (usually after 1-2 weeks). The volumes of the cultures had to be adjusted periodically to maintain a minimum of $\sim 5 \times 10^{5}$ cells/ $\mathrm{ml}$. The supernatants of transformed cultures were collected, passed through a $0.45-\mu \mathrm{m}$ filter, and frozen at $-70^{\circ} \mathrm{C}$ as a source of virus. Myeloid conditions consisted of standard growth medium to which 5-10 U/ml of crude cMGF (ConA spleen-conditioned medium; Leutz et al. 1984) was added. Erythroid conditions consisted of "blastoderm medium" composed of $277 \mathrm{ml}$ of DMEM, $38 \mathrm{ml}$ of $\mathrm{H}_{2} \mathrm{O}, 40 \mathrm{ml}$ of fetal calf serum, $10 \mathrm{ml}$ of chicken serum, $14 \mathrm{ml}$ of $5.6 \% \mathrm{NaHCO}_{3}$, conalbumin $(1.5 \mathrm{ml}$ of $15 \mathrm{mg} / \mathrm{ml}), 320 \mu \mathrm{l}$ of $\beta$-mercaptoethanol $(0.1 \mathrm{M}), 220 \mu \mathrm{l}$ of insulin $(1.7 \mathrm{mg} / \mathrm{ml})$, and a standard complement of antibiotics. This medium was supplemented with $2 \%$ anemic chicken serum as a source of erythropoietin during the first 2 days of cocultivation.

\section{In vitro transformation of blastoderm cells}

Blastoderm cultures were obtained from 2-day-old chick embryos (stages 10-12) essentially as described by Moscovici et al. (1983). They were infected and then seeded in blastoderm medium containing $2 \%$ anemic serum, 5-10 U/ml of crude cMGF, and $0.8 \%$ Methocel as described earlier (Graf et al. 1981). These conditions allowed the outgrowth of both transformed myeloid and transformed erythroid cells. Transformed colonies were isolated 7-10 days after infection with a bent and drawn-out Pasteur pipette and seeded in microtiter wells for expansion in liquid culture.

\section{Establishment of cell lines}

Cell lines transformed by the myb-ets and myb/ets viruses were established by first expanding rapidly growing blastoderm-derived transformed erythroid cultures to $100 \times 10^{6}$ to $500 \times 10^{6}$ cells and then gradually reducing the pool size as the cells began to enter into crisis. HD24, established from a pool of E26-transformed clones, has been maintained for $>1.5$ years in continuous culture. HD51 and HD57 were established from two clones transformed by E26 and have been maintained for $>1$ year in culture. HD37 and HD44 were established from two clones transformed by $\mathrm{myb}^{77} / \mathrm{ets}^{68}$ virus and were maintained for $\sim 1.5$ years in culture. The origin of the HD3 cell line, transformed by ts34AEV, has been described earlier (Beug et al. 1982).

\section{Analysis of proteins}

Myb and Ets proteins were analyzed by radioimmunoprecipitation using anti-Myb (Ness et al. 1987) and anti-Ets sera (Ghys- 
dael et al. 1986). Erythroid cells $\left(20 \times 10^{6}\right)$ were labeled for $1 \mathrm{hr}$ with $\left.400 \mu \mathrm{Ci} / \mathrm{ml}{ }^{35} \mathrm{~S}\right]$ methionine according to Radke et al. (1982). Lysis of cells and immunoprecipitation of proteins were carried out essentially as described by Ghysdael et al. (1986).

\section{Cell antigens}

Immunofluorescent staining of living cells was performed essentially as described earlier (Radke et al. 1982). For lineage determination, $1 \times 10^{6}$ to $2 \times 10^{6}$ cells were incubated for $\mathrm{l} \mathrm{hr}$ at $4^{\circ} \mathrm{C}$ with the anti-myeloblast mouse monoclonal antibody $51 / 2$ (Kornfeld et al. 1983) and with the erythroblast-specific rabbit antiserum K26 (Beug et al. 1979) as first antibodies. After washing, cells were incubated for $1 \mathrm{hr}$ at $4^{\circ} \mathrm{C}$ with fluorescein (FITC)-conjugated goat anti-mouse and rhodamine-conjugated goat anti-rabbit second antibodies. To identify differentiation stage-specific cell-surface markers, the mouse monoclonal antibodies MEP17, MEP21, and MEP26, which were raised against E26-transformed erythroid cells $(\mathrm{MEP}=\underline{\mathrm{M}}$ yb-Ets transformed progenitors; T. Graf et al., in prep.), as well as JS3 and JS4 (Schmidt et al. 1986), were used as first antibodies, with FITCconjugated goat anti-mouse serum as a second antibody. Histone $\mathrm{H} 5$ was detected by immunofluorescence as described earlier (Beug et al. 1979).

\section{Cytochemical assays}

Staining of erythroid cells for expression of hemoglobin with benzidine at acid $\mathrm{pH}$ was done according to Orkin et al. (1975); $200-300$ cells were counted for each cell clone analyzed. For the evaluation of morphology and hemoglobin content, erythroblasts were subjected to cytocentrifugation, stained with benzidine at neutral $\mathrm{pH}$, and counterstained with Giemsa (Diff Quick, Harleco) as described previously (Beug et al. 1982). To detect promyelocyte-specific granules, transformed myeloid cells were subjected to cytocentrifugation and stained with astra blue as described by Golay et al. (1988).

\section{Determination of population doubling capacities}

To determine the lifespans of erythroid cells transformed by various viral constructs, a number of individually transformed colonies freshly isolated from Methocel were expanded in blastoderm medium (see above) and kept in $500-\mu l$ cultures in 24 well dishes until their lifespan expired (maximally after 9 weeks). Whenever the cell densities exceeded $2 \times 10^{6}$ cells $/ \mathrm{ml}$, the cultures were diluted twofold. For each colony, the cumulative cell number was calculated from the actual cell number and from the number of dilution steps. The cell numbers of those clones that already died at the level of microtiter plates were counted or estimated. The cumulative cell number was used to calculate the number of population doublings.

\section{Acknowledgments}

We thank D. Leprince for providing a cDNA clone encoding the Ets-I protein (also called p68 $8^{\text {c-ets-1 }}$ ), J. Ghysdael for the anti-Ets serum, H. Beug for the JS3 and IS4 antisera, B. Vennström for discussions, D. Bohmann, J.S. Lipsick, and S.A. Ness for help with the manuscript, S. Grieser for technical assistance, H. Davies-Rück and $\mathrm{H}$. Fry for typing the manuscript, and S. Bednarczyk for help with the construction of graphics.

The publication costs of this article were defrayed in part by payment of page charges. This article must therefore be hereby marked "advertisement" in accordance with 18 USC section 1734 solely to indicate this fact.

\section{References}

Beug, H., A. von Kirchbach, G. Döderlein, J.F. Conscience, and T. Graf. 1979. Chicken hematopoietic cells transformed by seven strains of defective avian leukemia viruses display three distinct phenotypes of differentiation. Cell 18: 375390.

Beug, H., G. Döderlein, C. Freudenstein, and T. Graf. 1982. Erythroblast cell lines transformed by temperature-sensitive mutants of avian erythroblastosis virus: A model system to study erythroid differentiation in vitro. I. Cell. Physiol. (suppl.) 1: 195-207.

Beug, H., A. Leutz, P. Kahn, and T. Graf. 1984. Ts mutants of E26 leukemia virus allow transformed myeloblasts, but not erythroblasts or fibroblasts, to differentiate at the nonpermissive temperature. Cell 39: 579-588.

Bosselut, R., J.F. Duvall, A. Gegonne, M. Bailly, A. Hemar, J. Brady, and J. Ghysdael. 1990. The product of the c-ets-1 protooncogene and the related Ets2 protein act as transcriptional activators of the long terminal repeat of human $T$ cell leukemia virus HTLV-1. EMBO J. 9: 3137-3145.

Boyle, W.J., M.A. Lampert, J.S. Lipsick, and M.A. Baluda. 1984. Avian myeloblastosis virus and E26 virus oncogene products are nuclear proteins. Proc. Natl. Acad. Sci. 81: 4265-4269.

Curran, T. and B.R. Franza Jr. 1988. Fos and Jun: The AP-1 connection. Cell 55: 395-397.

Frykberg, L., T. Metz, G. Brady, M. Introna, H. Beug, B. Vennström, and T. Graf. 1988. A point mutation in the DNA binding domain of the $\mathrm{v}-\mathrm{my} b$ oncogene of E26 virus confers temperature sensitivity for transformation of myelomonocytic cells. Oncogene Res 3: 313-322.

Fuerstenberg, S., H. Beug, M. Introna, K. Khazaie, A. Muñoz, S.A. Ness, K. Nordström, J. Sap, I. Stanley, M. Zenke, and B. Vennström. 1990. Ectopic expression of the erythrocyte band 3 anion exchange protein using a new avian retrovirus vector. I. Virol. 64: 5891-5902.

Gandrillon, O., P. Jurdic, B. Pain, C. Debois, J.J. Madjar, M.G. Moscovici, C. Moscovici, and J. Samarut. 1989. Expression of the v-erbA product, an altered nuclear hormone receptor, is sufficient to transform erythrocytic cells in vitro. Cell 58: $115-121$.

Ghysdael, J., P. Gegonne, P. Pognonec, D. Dernis, D. Leprince, and D. Stehelin. 1986. Identification and preferential expression in thymic and bursal lymphocytes of a c-ets oncogeneencoded $\mathrm{M}_{\mathrm{r}} 54,000$ cytoplasmic protein. Proc. Natl. Acad. Sci. 83: 1714- 1718 .

Golay, J., M. Introna, and T. Graf. 1988. A single point mutation in the v-ets oncogene affects both erythroid and myelomonocytic cell differentiation. Cell 55: 1147-1158.

Graf, T., A. von Kirchbach, and H. Beug. 1981. Characterization of the hematopoietic target cells of AEV, MC29 and AMV avian leukemia viruses. Exp. Cell Res. 131: 331-343.

Graf, T., S. Grieser, and M. Nunn. 1987. Analysis in the dual lineage specificity of E26 avian leukemia virus. 38. Mosbach Colloquium. In Molecular basis of viral and bacterial pathogenesis. Cell cycle and oncogenes (ed. W. Goebel and R. Rott), pp. 91-94. Springer Verlag, Berlin/Heidelberg.

Gunther, C.V., J.A. Nye, R.S. Bryner, and B.J. Graves. 1990. Sequence-specific DNA binding of the proto-oncogene ets-1 defines a transcriptional activator sequence within the long terminal repeat of the Moloney murine sarcoma virus. Genes \& Dev, 4: 667-679.

Ho, I.-C., N.K. Bhat, L.R. Gottschalk, T. Lindsten, C.B. Thomp- 
son, T.S. Papas, and J.M. Leiden. 1990. Sequence specific binding of human Ets-1 to the T cell receptor $\alpha$ gene enhancer. Science 250: 814-818.

Ibanez, C.E. and J.S. Lipsick. 1990. Trans-activation of gene expression by v-myb. Mol. Cell. Biol. 10: 2285-2293.

Introna, M., J. Golay, J. Frampton, T. Nakano, S.A. Ness, and T. Graf. 1990. Mutations in $v-m y b$ alter the differentiation of myelomonocytic cells transformed by the oncogene. Cell 63: $1287-1297$.

Klempnauer, K.-H., G., Symonds, G.I. Evans, and J.M. Bishop. 1984. Subcellular localization of proteins encoded by oncogenes of avian myeloblastosis virus and avian leukemia virus E26 and by the chicken c-myb gene. Cell 37: 537-547.

Klempnauer, K.H., H. Arnold, and H. Biedenkapp. 1989. Activation of transcription by v-my $b$ : Evidence for two different mechanisms. Genes \& Dev. 3: 1582-1589.

Klemsz, M.J., S.R. McKercher, A. Celada, C. van Beveren, and R.A. Maki. 1990. The macrophage and B cell-specific transcription factor PU.1 is related to the ets oncogene. Cell 61: 113-124.

Kornfeld, S., H. Beug, G. Döderlein, and T. Graf. 1983. Detection of avian hematopoietic cell surface antigens with monoclonal antibodies to myeloid cells: Their distribution on normal and leukemic cells of various lineages. Exp. Cell Res. 143: 383-394.

Kozak, M. 1984. Compilation and analysis of sequences upstream of the translational start site in eukaryotic mRNAs. Nucleic Acids Res. 12: 857-872.

Leprince, D., M. Duterque-Coquillaud, R.P. Li, H. Catherine, A. Flourens, B. Debuire, and D. Stehelin. 1988. Alternative splicing within the chicken c-ets-1 locus: Implications for transduction within the E26 retrovirus of the c-ets protooncogene. J. Virol. 62: 3233-3241.

Leprince, D., I.C. Gesquiere, and D. Stehelin. 1990. The chicken cellular progenitor of the v-ets oncogene, $\mathrm{p} 68^{\mathrm{c}-\mathrm{ets}-1}$, is a nuclear DNA-binding protein not expressed in lymphoid cells of the spleen. Oncogene Res. 5: 255-266.

Leutz, A., H. Beug, and T. Graf. 1984. Purification and characterization of cMGF, a novel chicken myelomonocytic growth factor. EMBO I. 3: 3191-3197.

Lipsick, J.S. 1987. v-myb does not prevent the expression of c-myb in avian erythroblasts. J. Virol. 61: 3284-3287.

Lipsick, J.S., C.E. Ibanez, and M.A. Baluda. 1986. Expression of molecular clones of v-myb in avian and mammalian cells independently of transformation. I. Virol. 59: 267-275.

Metz, T., T. Graf, and A. Leutz. 1991. Activation of cMGF expression is a critical step in avian myeloid leukemogenesis. $E M B O \%$. (in press).

Moreau-Gachelin, F., D. Ray, M.-G. Mattei, P. Tambourin, and A. Tavitian. 1989. The putative oncogene spi-1: Murine chromosomal localization and transcriptional activation in murine acute erythroleukemias. Oncogene 4: 1440-1456.

Moreau-Gachelin, F., A. Tavitian, and P. Tambourin. 1988. Spi1 is a putative oncogene in virally induced murine erythroleukemias. Nature 331: 277-280.

Moscovici, M.G., P. Jurdic, J. Samarut, L. Gazzolo, C.V. Mura, and C. Moscovici. 1983. Characteristics of the hemopoietic target cells for the avian leukemia virus E26. Virology 129: $65-78$

Ness, S.A., H. Beug, and T. Graf. 1987. V-myb dominance over $\mathrm{v}-\mathrm{myc}$ in doubly transformed chick myelomonocytic cells. Cell 51: 41-50.

Ness, S.A., A. Marknell, and T. Graf. 1989. The v-myb oncogene product binds to and activates the promyelocyte-specific mim-1 gene. Cell 59: 1115-1125.

Nishina, Y., H. Nakagoshi, F. Imamoto, T.J. Gonda, and S. Ishii.
1989. Trans- activation by the c-myb proto-oncogene. $\mathrm{Nu}$ cleic Acids Res. 17: 107-117.

Nunn, M.F. and T. Hunter. 1989. The ets sequence is required for induction of erythroblastosis in chickens by avian retrovirus E26. I. Virol. 63: 398-402.

Orkin, S.H., F.I. Harosi, and P. Leder. 1975. Differentiation in erythroieukemic cells and their somatic hybrids. Proc. Natl. Acad. Sci. 72: 98-102.

Radke, K., H. Beug, S. Kornfeld, and T. Graf. 1982. Transformation of both erythroid and myeloid cells by E26, an avian leukemia virus that contains the myb gene. Cell 31: 643653.

Schmidt, J.A., J. Marshall, M.K. Hayman, G. Döderlein, and H. Beug. 1986. Monoclonal antibodies to novel erythroid differentiation antigens reveal specific effects of oncogenes on the leukemic cell phenotype. Leuk. Res. 10: 257.

Shen-Ong, G.L.C. 1990. The myb oncogene. Biochim. Biophys. Acta 1032: 39-52.

Vennström, B., L. Fanshier, C. Moscovici, and J.M. Bishop. 1980. Molecular cloning of the avian erythroblastosis virus genome and recovery of oncogenic virus by transfection of chicken cells. I. Virol. 36: 575-585.

Wasylyk, B., C. Wasylyk, P. Flores, A. Begue, D. Leprince, and D. Stehelin. 1990. The c-ets proto-oncogenes are transcription factors that cooperate with c-fos and c-jun for transcriptional activation. Nature 346: 191-193.

Weston, K. and J.M. Bishop. 1989. Transcriptionai activation by the v-myb oncogene and its cellular progenitor, c-myb. Cell 58: 85-93. 


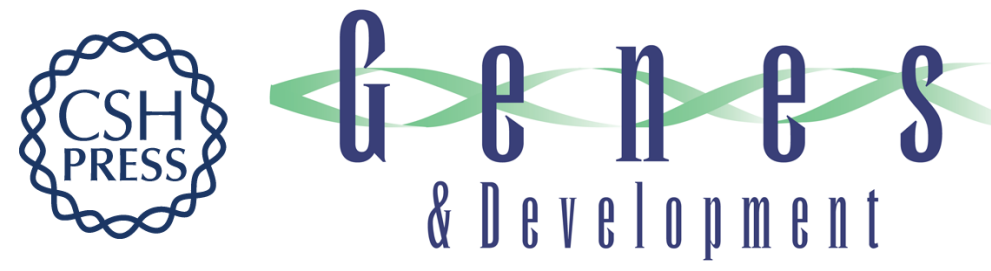

\section{v-myb and v-ets transform chicken erythroid cells and cooperate both in trans and in cis to induce distinct differentiation phenotypes.}

T Metz and T Graf

Genes Dev. 1991, 5:

Access the most recent version at doi:10.1101/gad.5.3.369

References

This article cites 40 articles, 11 of which can be accessed free at:

http://genesdev.cshlp.org/content/5/3/369.full.html\#ref-list-1

License

Email Alerting

Receive free email alerts when new articles cite this article - sign up in the box at the top

Service right corner of the article or click here.

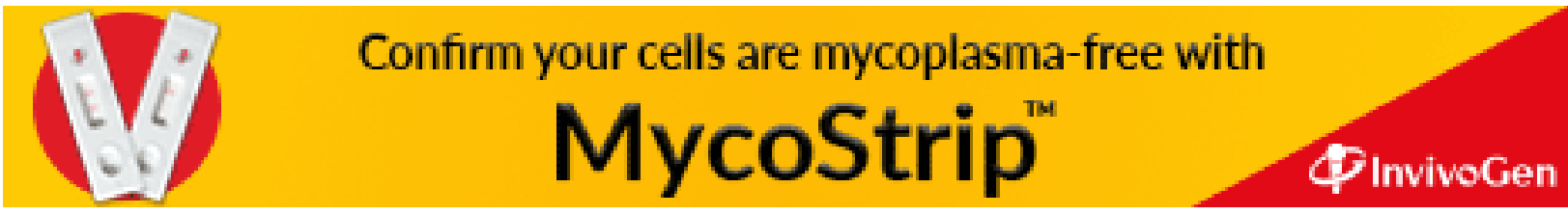

